\title{
Human Papillomavirus-Related Adenosquamous Carcinoma
}

National Cancer Institute

\section{Source}

National Cancer Institute. Human Papillomavirus-Related Adenosquamous Carcinoma. NCI Thesaurus. Code C97046.

An adenosquamous carcinoma associated with the presence of human papillomavirus infection. 